\title{
Some parasites causing diarrhea in goats in Beni-Suef Governorate
}

\author{
S. M. Abo El-Hadid' ${ }^{1}$ H. S. Lotfy ${ }^{2}$ \\ ${ }^{1}$ Department of Parasitology, Faculty of Veterinary Medicine, Beni-Suef University, Beni-Suef, Egypt \\ ${ }^{2}$ Animal Health Institute, Beni-Suef, Egypt
}

\begin{abstract}
A total of 100 fecal samples from goats were coprologically examined to investigate the main cause of diarrhea. Animals were divided according to the age into 3 groups (7-35 days, 35 days - 6month and over one year). The results revealed that Eimeria species was the most predominant parasite $(70 \%)$, the parasitic gastroenteritis (28\%) and Cryptosporidium species (21\%). Ten species of Eimeria were identified from the infected animals, E. hirci, E. arloingi, E. intericata, E. ahsata, E. christenseni, E. marisca, E. crandalis, $E$. weybridegenesis, $E$. faurei and E. ovina. Three species of parasitic gastroenteritis (Haemonchus contortus, Ostertagia species and Trichostrongylus species). Cryptosporidium oocysts were found common in young goats.
\end{abstract}

The goat is one of the most resourceful and efficient ruminants (Mussman, 1982). Moreover, it has easy handling, independence and adaptability to living free, modest feeding requirements, good tolerance to climate in different regions and effective conversion of limited resources into milk, meat and hides are desired factors favouring the goat as a stock animal for small scale farmers (Balicka-Ramisz, 1999; Harper and Penzhorn, 1999). Goat meat is much desired and is considered a delicacy in the diet of the Egyptian people. The level of off-take from goats is higher than sheep (Ndamukong et al., 1987).

Parasitic affections induce severe losses of the productive parameters of goats. System of goat breeding specially by small owners did not apply any medical care for individual animals. There are field infection and reinfection of goats by different parasites. The parasites which were recorded in Egypt in goats include Haemonchus contortus (Hassan, 1985) and Trichostrogylus axi about 40\% (Salem et al., 1991). Parasites of gastrointestinal tract that include, Haemoncus and Trichostrongylus, Bunostomum were recorded by Shawkat et al. (1991) in Kafer El Sheihk.

Diarrhea is the main symptom associated with these parasitic infections especially in newly born animals. The parasitic infections lead to rapid morbidity of the affected animals that may end with their death. This condition was recorded in high level infectio by parasitic gastroentritis, coccidian and cryptosporidial infection. Coccidiosis is a wide spread serious economic disease affecting pre weaned and recently weaned kids (Foryet, 1990; Dai et al., 1991; Smith and Sherman, 1994, Schafer et al., 1995). Henin (1997) found Eimiria species oocysts in $85.92 \%$ of the examined goats in Beni-Suef Governorate.

Cryptosporidium parvum was found in 100 $\%$ of newborn kids in Danish goats (Thamsborg et al., 1990). Where Munoz et al. (1994) found C. parvum oocysts in feces of 6 out of 45 goat kids. In Egypt, Abou El Hassan, (1996) detected Cryptosporidium oocyst in $16.5 \%$ of 200 diarrheic goat kids.

The present study spots the light on enteric parasites as a cause of losses and mortalities in goats with special reference to those of less than 2 months old in Beni-Suef city.

\section{Materials and methods}

Samples. A total number of 100 goat diarrheic feacal samples were collected from different localities in Beni-Suef city. The animals age range from 7 days to 4 years. The fecal samples were identified by owner name, locality, age and complain. The fecal samples were transferred directly for examination to the department of Parasitology, Faculty of Vetrinary Medicine, Beni-Suef.

Examination of samples. Fecal samples were examined using concentration Floatation technique and the eggs were counted using MacMaster technique according to the method described by Soulsby (1982) for counting of PGE eggs and coccidia oocysts per gram feces.

Modified Ziehl-Neelsen technique according to Henriksen and Pohlenz, (1981) was applied for diagnosis of Cryptosporidium oocyst. 


\section{Results and Discussion}

The data in table (1) revealed that coccidian infection appear as the most common cause of diarrhea in examined goat $(70 \%)$ followed by parasitic gatroentritis (28\%) and the lowest percent was recorded for Cryptosporidium species $(21 \%)$. Concerning the relation between age of examined animals and their parasitic infection, Cryptosporidium is the most common one in young animals (gp.1) $50 \%$ followed by different Eimeria species (40\%) especially in animals suffered from diarrhea. No parasitic nematode eggs could be detected in the examined young goats at the early age. Concerning the animals in gp2 (35 days- 6 months age), the most common infection was by Eimeria spp. $85.71 \%$ followed by PGE eggs (28.57\%) and Cryptosporidium infection $20 \%$. In gp3 (over one year age), the main diagnosed parasite was Eimeria spp. (71.43\%) then PGE eggs in $(51.43 \%)$ and the lowest parasitic infection was by Cryptosporidium (5.71\%). Regarding the mixed infection with these parasites, it was noticed that Eimeria spp. and PGE in two groups (over 35days and over $6 \mathrm{~m}$.) and was not found in group1 (7-35days) and higher in gp3 (over one year) $37.14 \%$. On the other hand the study did not detect a relation between kind of parasitic affection and condition of feces except in infection by Cryptosporidium, it appears to be the main cause of diarrhea in young age. The most predominant species of Eimeria in Table (2) was Eimeria intricata $(85.71 \%)$ followed by E. arloingi $(74.28 \%)$ and less predominant species were E. marisca, E. ovina and E. faurei (14.28\%). The number of oocyst per gram (opg), ranged from 750 to 1250 opg. These numbers decreased with progress in age. It was cleared from table (3), Haemonchus contortus was the most common nematodes appeared in these animals $(71.43 \%)$ and also had the higher number of eggs per gram of feces (epg) $650 \mathrm{epg}$, followed by Ostertagia sp. $(35.71 \%)$ and 450epg. The less common nematodes was Trichostrongylus sp. at (21.43\%) and 450epg. Regarding the age, Ostertagia sp. and Trichostrongylus sp. eggs appeared in early or more common in young age than Haemonchus contortus, this depend on the wide range host of Ostertagia sp. and Trichostrongylus, the habits of the young animals to graze any object in the environment and low level of immunity (more susceptible). It was noticed that infection by these nematodes could be mixed Eimeria infection in goats was $(89.9 \%)$ in adults and $94.0 \%$ of kids with OPG of less than 1000. Twelve species of Eimeria were identified. The percentage of animals harbouring different species were; E. alijevi and E. ninakohlyakimovae, 99\%; E. hirci, 83.5\%, E. arloingi, $80.6 \%$; E. caprina, $77.6 \% ; \quad E$. aspheronica, $64.8 \%, E$. ahsata, 63\%, E. christenseni, $60 \%$; E. granulose, $42.8 \%, E$. pallida, $6.2 \%$; E. intricata, $2 \%$ and E. punctata $0.3 \%$. Two percent of goats harboured three species, $5.6 \%$ four, $9.5 \%$ five, $26.3 \%$ six, $25.7 \%$ seven, $23.7 \%$ eight, $6.3 \%$ nine, $0.6 \%$ ten and $0.3 \%$ eleven species (Chhabra and Pandey (1991), while Henin, (1998) found Eimeria species infect goats were E.ninakohlyakimovae (69.68\%), E. christenseni (51.83\%), E. arloingi (50.12\%), E. hirci (20.53\%), E. caprina $(9.77 \%)$ in Beni-Suef Governorate. Balika-Ramisz (1999) found 9 species of Eimeria, E. chrestenseni, E. ninakohlyakimovae, E. arloingi, E. jolchijev, E. alijevi, E. asphoronica, E. caprina, E. caprovina and E. hirci. $91 \%$ of adults and $100 \%$ of kids were infected.

Faizal and Rajapakse (2001) recorded Eimeria species in $88 \%$ in Kids and $91 \%$ of young goats and $83 \%$ of adults. Seven species of Eimeria were identified, E. ninakohlyakimovae (31\%), E. alijevi (29\%), E. arloingi (21\%), E. christenseni $(7 \%)$ and E. hirci (3\%). More over, AboShehada and Abo-Farieha (2003) found 54\% of the examined goats were infected with at least one Eimeria species. More young goats (< 1year) $(66 \%)$ were infected with at least one species of Eimeria compared to $49 \%$ adult $>1$ year-old goats. 8 Eimeria species were identified, E. arloingi, E. caprina,E. alijevi being the most prevalent in the adults, $E$. ninakohlyakimovae, E. asphorinica and E. caprina being the most common species amongst the kid population. In addition, $E$. caprovina and E. parva were found common in both age groups. But, Agyei et al. (2004) recorded Eimeria species in goat kids as, E. arloingi $(20.50 \%), \quad E$. ninakohlyakimovae $(17.2 \%)$, E. caprina $(15.07 \%)$, E. jolchijevi $(11.42 \%)$, E. aspheronica $(8.70 \%)$, E. pallida (5.31\%), E. hirci $(3.20 \%)$ and E. christenseni $(2.84 \%)$. Also, the same result reported by Jalila, et al., (1998) in Malaysia and Koudela and 
Table (1): Prevalence of enteric parasites causing diarrhea in goats.

\begin{tabular}{|c|c|c|c|c|c|c|c|c|c|c|}
\hline \multirow{2}{*}{$\begin{array}{c}\text { Group } \\
\text { age }\end{array}$} & \multirow{2}{*}{$\begin{array}{l}\text { Form of } \\
\text { feces }\end{array}$} & \multirow{2}{*}{$\begin{array}{c}\text { Exam. } \\
\text { no }\end{array}$} & \multicolumn{2}{|c|}{$\begin{array}{c}\text { Parasitic } \\
\text { gastroenteritis }\end{array}$} & \multicolumn{2}{|c|}{ Eimeria species } & \multicolumn{2}{|c|}{ Mixed infection* } & \multicolumn{2}{|c|}{$\begin{array}{c}\text { Cryptosporidium } \\
\text { spp. }\end{array}$} \\
\hline & & & No. & $\%$ & No. & $\%$ & No. & $\%$ & No. & $\%$ \\
\hline \multirow{2}{*}{ 7- 35 days } & diarrheic & 20 & 0 & 0 & 8 & 40 & 0 & 0 & 10 & 50 \\
\hline & formed & 10 & 0 & 0 & 7 & 70 & 0 & 0 & 2 & 20 \\
\hline \multicolumn{2}{|c|}{ Total } & 30 & 0 & 0 & 15 & 50 & 0 & 0 & 12 & 40 \\
\hline 35 day- 6 & diarrheic & 20 & 5 & 25 & 18 & 90 & 5 & 25 & 4 & 20 \\
\hline months & formed & 15 & 5 & 30 & 12 & 80 & 6 & 40 & 3 & 20 \\
\hline \multicolumn{2}{|c|}{ Total } & 35 & 10 & 28.57 & 30 & 85.71 & 11 & 31.43 & 7 & 20 \\
\hline Over one & diarrheic & 15 & 6 & 40 & 10 & 66.66 & 5 & 30 & 2 & 6.66 \\
\hline years & formed & 20 & 12 & 60 & 15 & 75 & 8 & 40 & 0 & 0 \\
\hline Total & & 35 & 18 & 51.43 & 25 & 71.43 & 13 & 37.14 & 2 & 5.71 \\
\hline \multicolumn{2}{|c|}{ Total } & 100 & 28 & 28 & 70 & 70 & 24 & 24 & 21 & 21 \\
\hline
\end{tabular}

* Mixed infection: infection by coccidia and PGE (parasitic gastroenteritis)

Table (2): Different types of Eimeria spp. oocysts diagnosed in infected goats.

\begin{tabular}{|c|c|c|c|c|c|c|}
\hline Type & $\begin{array}{l}\text { Measurements } \\
\text { Max. }\end{array}$ & Min. & Mean (um) & $\begin{array}{c}\text { No. of } \\
\text { infected oats }\end{array}$ & $\%$ & $\begin{array}{c}\text { No. OPG } \\
\text { (mean) }\end{array}$ \\
\hline E. intricata & $49 \times 35$ & $45 \times 30$ & $47 \times 32$ & 60 & 85.71 & 900 \\
\hline E. crandalis & $26 \times 18$ & $22 \times 16$ & $24 \times 17$ & 44 & 62.85 & 1100 \\
\hline E. weybridgensis & $26 \times 18$ & $22 \times 16$ & $24 \times 17$ & 36 & 51.43 & 850 \\
\hline E. marisca & $20 \times 14$ & $18 \times 12$ & $19 \times 13$ & 10 & 14.28 & 1200 \\
\hline E. hirci & $24 \times 20$ & $22 \times 18$ & $23 \times 19$ & 40 & 57.14 & 1200 \\
\hline E. ahsata & $40 \times 26$ & $37 \times 24$ & $39 \times 25$ & 50 & 71.42 & 1250 \\
\hline E. faurei & $29 \times 21$ & $27 \times 20$ & $28 \times 21$ & 10 & 14.28 & 850 \\
\hline E. ovina & $32 \times 21$ & $30 \times 19$ & $31 \times 20$ & 10 & 14.28 & 750 \\
\hline E. christenseni & $38 \times 25$ & $38 \times 25$ & $38 \times 25$ & 20 & 28.57 & 900 \\
\hline E. arloingi & $28 \times 19$ & $26 \times 17$ & $27 \times 18$ & 52 & 74.28 & 1000 \\
\hline
\end{tabular}

Table (3): Different PGE eggs diagnosed in infected goats

\begin{tabular}{ccccc}
\hline Parasite & \multicolumn{2}{c}{ Infected animal } & No. of EPG (mean) & $\begin{array}{c}\text { Common age of } \\
\text { infection }\end{array}$ \\
\hline No. & $\mathbf{\%}$ & 71.43 & 650 & Over 6 months \\
Ostertagia spp. & 20 & 35.71 & 450 & Over 35 days \\
Trichstrongylus spp. & 6 & 21.43 & 450 & Over 35 days \\
Total & 28 & 28 & - & - \\
\hline
\end{tabular}

Bokova (1998) in Czech Republic.

Gastrointestinal nematodes eggs were found in $89 \%$ of the kids, $94 \%$ of the young goats and $84 \%$ of the adult goats, included, Haemonchus contortus $(90 \%)$ followed by Oesophogostomum spp. (8.9\%), Trichostrongylus spp. (1\%), Faizal and Rajapakse, (2001), on the contrary with Hassan (1985) and Salem et al. (1991) 40\%. Ostertagia circumcinecta and Trichostrongylus axei were the most common species of parasitic nematodes in goats (Torina et al., 2004). But Nwosu et al. (1996) found that the most parasitic nematodes were Haemonchus contortus (90\%) and Trichostrongylus sp. (78.3\%) in Nigerian goats. Cryptosporidiosis in goats was found to be $29.1 \%$ of examined goats, Khalil (2000), while cryptosporidiosis $100 \%$ and $37.5 \%$ Thamsborg et al. (1990) and Hilali et al. (1998) in KSA respectively. Cryptosporidiosis seems to be mainly a problem in neonatal ruminants and considered to be an important agent in the etiology of the neonatal diarrhea syndrome of goat kids (Graff et al., 1999). 

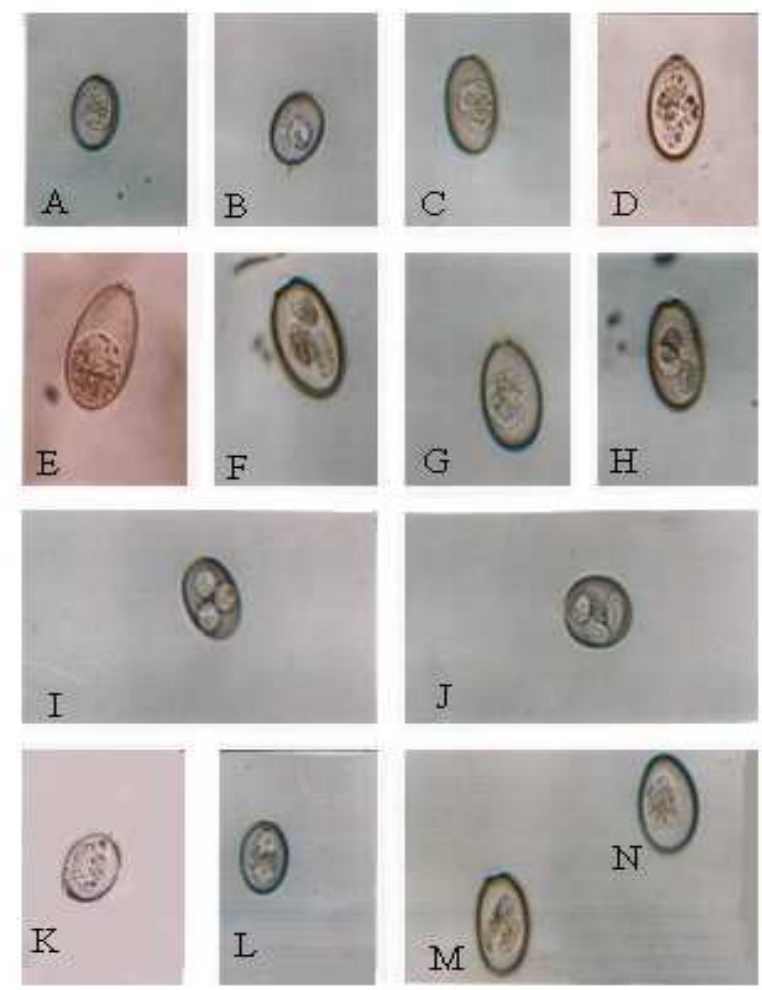

Plate (I):

a. E. hirci unsporulated oocyst

b. sporulated

c. $E$. arloingi unsporulated oocyst

d. sporulated

e. E. intericata unsporulated oocyst

f. sporulated

g. E. ahsata unsporulated oocyst

h. sporulated

i. E. crandalis (sporulated)

j. E. weybridegenesis (sporulated)

k. E. christenseni (sporulated)

l. E. marisca (sporulated)

m. E. ovina (sporulated)

n. E. faurei (sporulated)

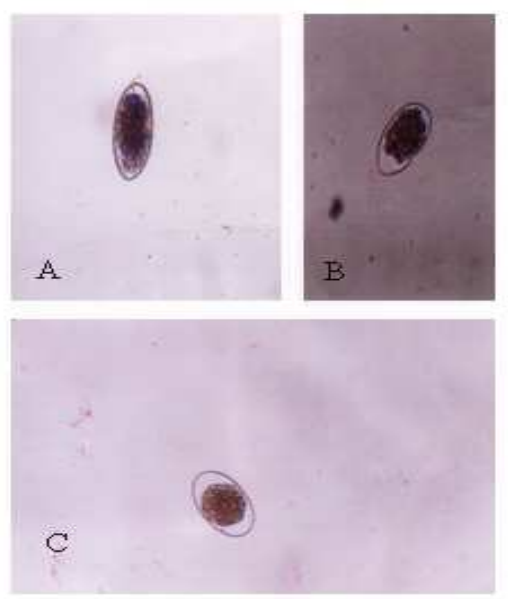

Plate (II):

a. Haemonchus contortus egg

b. Trichostrongylus sp. egg

c. Ostertagia sp. egg

\section{References}

Abo-Shehada, M. N. and Abo-Farieha, H. A. (2003): Prevalence of Eimeria species among goats in northern Jordan. Small Rumin. Res., 2003; 49: 109-113.

Abou El Hassan, (1996): Neonatal diarrhea in lambs and goat kids. $4^{\text {th }}$ Sci. Cong. Proc. April.3-6, 1996. Vet. Med. J. Giza, (44/92): 371-380.

Agyei, A. D.; Odonkor, M. and Osei-Somuah, A. (2004): Concurrence of Eimeria and helminth parasitic infections in West African Dwarf kids in Ghana. Small Rumin. Res., 51: 29-35.

Balicka-Ramisz, A. (1999): Studies on coccidiosis in goats in Poland. Vet. Parasitol., 81, 347-349.

Chhabra, R. C. and Pandey, V. S. (1991): Coccidia of goats in Zembabwe. Vet. Parasitol., 39(3-4): 199-205.

Dai, Y. B.; Lin, M. C.; Zhang, S. X. and Fu, A. O. (1991): Hepatic coccidiosis in goats. Int. J. Parasitol. , 21: 381-382.

Faizal, A. C. and Rajapakse, R. P. (2001): Prevalence of ccocidia and gasterointestinal nematode infections in cross bred goats in the dry areas of Sri Lanka. Small Rumin. Res., 40: 233-238.

Foryet, W. J.( 1990): Coccidiosis and cryptosporidiosis in sheep and goats. Vet. Clin. North. Am. Food. Anim. Pract., 6: 655-670.

Graff, D. C.; Vanopdenbosch, E.; Ortega-Mora, L. M.; Abbassi, H. and Peeters, J. E. (1999): A review of the importance of cryptosporidiosis in farm animals. Int. J. Parasitol., 29: 1269-287.

Hassan, M. G. (1985): Epizootological examinations on the gasterointestinal nematodes of cattle and buffaloes in Beni-Suef Governorate. Thesis, M. V. Sc. Vet. Parasitology Fac. Vet. Med. Cairo Univ., Egypt.

Henin, A. M. (1997): Some studies on coccidiosis in goats. Thesis, M. V. Sc. Fac. Vet. Med. Beni-Suef, Cairo Univ., Egypt.

Henriksen, S. A. and Pohlenz, J. F. L. (1981): Staining of Cryptosporidium by a modified Ziehl-Neelson technique. Act. Vet. Scand., 22, 594-596.

Herper, CK, Penzhorn, B. L.,(1999): Occurrence and diversity of coccidia in indifenous, Saanen and crossbred goats in South Africa. Vte. Parasitol., 82, 1-9.

Hilali, M.; Fatani, A. and El-Kharss, A. (1998): Diagnosis of Crysptosporidium parvum infecting sheep and goats suffering from diarrhea at El-Kharj, Saudi Arabia. Alex. J. Vet. Sci., 4: 91-96.

Jalila, A.; Dorny, P.; Sani, R.; Salim, N. B. and Vercruysse, J. (1998): Coccidia infections of goats in Selangor, Peninsular Malaysia. Vet. Parasitol., 74: 165172.

Khalil, F.A. (2000): Studies on cryptosporidium in sheep and goats. Ph. D. Thesis, Fac. Vet. Med. Cairo Univ., Egypt.

Koudela, B. and Bokova, A. (1998): Coccidiosis in goats in the Czech Republic. Vet. Parasitol., 76: 261-267. Munoz, M.; Lanza, L.; Alvarez, M. and Carmenes, P. (1994): Rotavirus excretion by kids in anaturally infected goat herd. Small Rum. Res., 14, 83-89.

Mussman, H. C. (1982): The animal as food resource for man with special reference to the role of animal disease. In. Proceedings of the Third International Conference On Goat Production and Disease. Tucson, AZ, Dairy Goat J., 9-11.

Ndamukong, K. J. N.; Sewell, M. M. H.; Asanji, M. F., (1987): Productivity of sheep and goats under three management systems at Bamenda, Cameroon. Trop. Anim. Health Prod., 19: 237-244 
Nwosu, C. O.; Orgunrinde, A. F. and Fagbemi, B. O. (1996): Prevalence and seasonal changes in the gastrointestinal helminthes of Nigerian goats. J. Helminth, 70: 329-33.

Salem, A. A.; Ghanem, F. M.; Hossein, H. I. and Oraby, F. A. (1991): Studies on gasterointestinal nematodes infestation in some zoo animals. Beni-Suef Vet. Med. J., 1: 387-392.

Schafer, K. A.; Stevenson, G. W. and Kazacos, K. R. (1995): Hepatic coccidiosis associated with hepatic necrosis in goats. Vet. Pathol., 723-727.

Shawkat, E. M.; Abdel-Halim, M. M.; Kubesy, A. A.; Rakha, G. M. and El-Fauomy, M. M. (1991): Clinical and therapeutic studies on parasitic gasteroentritis in sheep.
Vet. Med. J. Giza, 39: 237-254.

Smith, M. C. and Sherman, D. M. (1994): Goat medicine. Textbook of goat diseases, 312-318. Lea and Febiger, Malven, Pennsylvania, USA.

Soulsby, E. J. (1982): Helminths, Arthropods and Protozoa of domesticated animals $7^{\text {th }}$ ed.

Thamsborg, S. M.; Jorgensen, R. J. and Henriksen, S. (1990): Cryptosporidiosis in kids of dairy goats. Vet. Rec., $127(25 / 26):$ 627-628.

Torina, A.; Daras, S.; Marino, A. M.; Sparagono, O. A.; Vitale, F.; Reale, S. and Caracappa, S. (2004): Study of gastro-intestinal nematodes in Sicilian sheep and goats. Ann N Y Acad Sci., 1026: 187-194. 